\title{
AOR
}

Selected Papers of \#AolR2020:

The $21^{\text {st }}$ Annual Conference of the

Association of Internet Researchers

Virtual Event / 27-31 October 2020

\section{DEFENDING AGAINST SOCIAL MEDIA: HOW PUBLIC CRIMINAL DEFENSE HELPS US ADDRESS SOCIAL MEDIA GOVERNANCE}

\author{
Jeffrey Lane \\ Rutgers University \\ Fanny Anne Ramirez \\ Louisiana State University \\ Desmond Upton Patton \\ Columbia University
}

\section{Social Media Governance}

As justice-minded academics, we want to understand the role of social media in civil society with a vested interest in ensuring that social media promotes democracy and serves a pluralistic society fairly and equitably. Gillespie (2018) has helped frame this task in terms of issues that surround both governance of platforms and by platforms. This conceptual framework concerns the state and private governance policies that define the liability of social media companies for user behavior and content on their platforms (the of) and how companies manage the activity of their users to comply with these policies (the by). To understand and improve the role of social media in a democratic, pluralistic society we also want to know what state governments do with social media (Gorwa, 2019). The question of with focuses on how governments hold citizens liable for their social media use. To enforce state laws, states and social media companies cooperate to hold users accountable in court for their activity on the platform. Here, platforms serve as "conduits" (Langlois, 2013) or "extensions" (Nieborg \& Poell, 2018) of the state. Judicial governance is a rich area then to further conceptualize social media governance and identify equal access and fairness issues (Klonick, 2018) and appropriate checks and balances.

This paper focuses on the judicial context of the U.S. where social media companies, especially Facebook (Vaidhyanathan, 2018), have generally avoided state regulation

Suggested Citation (APA): Lane, J., Ramirez, F. A., \& Patton, D. U. (2020, October). Defending against social media: How public criminal defense helps us address social media governance. Paper presented at AoIR 2020: The 21 ${ }^{\text {th }}$ Annual Conference of the Association of Internet Researchers. Virtual Event: AolR. Retrieved from http://spir.aoir.org. 
and lack liability for user behavior/content (Mueller, 2015). This lack of company liability however has coincided with state cooperation to hold users themselves legally liable. Facebook Transparency figures indicate both that requests for user data from U.S. courts has increased steadily since 2013 , the first year this information was reported, and that Facebook overwhelmingly cooperates, complying with eighty-eight percent of the 47,457 total legal requests through June 2019. Social media companies have positioned themselves as impartial and noninterventionist (Gillespie, 2018), yet they operate as players in criminal justice-a role we know little about.

\section{The Case of New York Criminal Law and the Work of Public Defenders}

To understand the nature of state cooperation and how it bears on judicial governance, we draw on a study of public defenders in New York City in their efforts to defend against criminal prosecutions backed by social media. Public defenders provide legal representation to indigent criminal defendants, many of whom are persons of color, and their perspective helps us pinpoint equity and fairness issues. Of course, their perspective is itself biased by their role as advocates, and a complete picture would include the perspective of prosecutors, to which we were unable to gain access despite our best attempts. We did, however, develop an emerging understanding of judicial governance based on interviews with twenty public criminal defenders about: 1) where social media appears in their cases and the role it plays; 2 ) their access to user content and social media companies; and, 3) how they use social media as evidence and defend against it.

\section{Findings}

Based on the public defenders' grievances, we identified three problem areas around fair and equal access to the law. First, we heard concerns that the cooperation of social media companies was asymmetrical because they worked almost exclusively with law enforcement. Public defenders felt the companies shut them out. Defenders reported that they could only access social media content that was publicly available, provided by their client, or sent over in discovery (which prosecutors did not necessarily share). One public defender recounted jumping through numerous hoops just to serve Facebook, only to face stiff resistance: "it's extremely difficult on a criminal case to get them [Facebook] to respond to these subpoenas, they always file motions to quash the subpoena." By contrast, Facebook provides numerous accommodations to cooperate and comply with law enforcement requests (e.g. specialized personnel, an online portal). The public defenders treated cooperation between law enforcement and Facebook as a given even when they believed the connection to social media in the case was tangential at best.

Second, the public defenders complained about overly broad search warrants that were written to furnish the full contents of a suspect's social media account to which judges readily signed off. Such vast, networked data opened the possibility of charging new crimes in a fishing expedition and exposed the privacy of the defendant and their network (e.g., nudes, family photos). Said one public defender of the warrant used against his client, "when they have access to your Facebook account like they did to [his 
client's name], they got every post that he ever posted, everything he deleted, every private message that he ever sent since 2011 , like since he was 11 years old."

Third, public defenders complained about the use and admission of prejudicial evidence that played to negative, racial stereotypes of their clients. Defenders rarely reported the appearance in their cases of positive images or pro-social behavior on social media. Instead, they were typically defending against "damning" evidence. One defender gave the example of the admission of photos to establish the height of his client, a black man, that prosecutors took from his client's Instagram because they were likely to be construed as "thuggish" that were selected over numerous photos "holding his two-yearold daughter."

\section{Governance Implications}

Our findings suggest a few lessons for social media governance. First, we uncovered issues with what Gillespie (2018) calls "the middle-ness" of platforms. For the defenders, the social media companies were too far on the side of law enforcement and not in the middle enough. Social media companies need to develop more nearly equitable cooperation practices to level the playing field for law enforcement and public defense, either intervening on both sides or for neither. Second, judges should require law enforcement to specify the type and timeline of social media data sought in a search warrant to limit the chance of fishing expeditions. We also see the need for restrictions on the handling and disposition of networked data that identifies third parties unrelated to crimes being investigated. Third, we believe judicial actors would benefit from the cultural context of social media use to evaluate its admissibility and weight as criminal evidence. Given the selective, strategic, and curated nature of the disclosures made on these platforms and the particular impression management strategies of and biases against members of racial and ethnic minority groups (Lane, 2019), we suggest that admissibility protocols and disclaimers on admitted materials become standard practice in the criminal justice field. We suggest looking to these judicial correctives to reduce biases and inequities in other areas of governance with social media as well. We also suggest studying the work of actors directly involved in social media governance practices (Roberts, 2019) to guide future empirical research.

\section{References}

Gillespie, T. (2018). Governance of and by platforms. In J. Burgess, T. Poell, \& A. E. Marwick (Eds.), The SAGE Handbook of Social Media (pp. 254-278). London: SAGE.

Gorwa, R. (2019). What is platform governance? Information, Communication \& Society, 22(6), 854-871. doi:10.1080/1369118X.2019.1573914

Klonick, K. (2018). The New Governors: The People, Rules, and Processes Governing Online Speech. Harvard Law Review, 131(6), 1598.

Lane, J. (2019). The Digital Street: Oxford University Press. 
Langlois, G. (2013). Participatory Culture and the New Governance of Communication: The Paradox of Participatory Media. Television \& New Media, 14(2), 91-105. doi:10.1177/1527476411433519

Mueller, M. L. (2015). Hyper-transparency and social control: Social media as magnets for regulation. Telecommunications Policy, 39(9), 804-810. doi:10.1016/j.telpol.2015.05.001

Nieborg, D. B., \& Poell, T. (2018). The platformization of cultural production: Theorizing the contingent cultural commodity. New Media \& Society, 20(11), 4275-4292. doi:10.1177/1461444818769694

Roberts, S. T. (2019). Behind the Screen: Content Moderation in the Shadows of Social Media. New Haven, CT: Yale University Press.

Vaidhyanathan, S. (2018). Antisocial Media: How Facebook Disconnects Us and Undermines Democracy. New York, NY: Oxford University Press. 